\title{
Chapter 10 \\ Negative Spillovers in International \\ Corporate Taxation and the European \\ Union
}

\author{
Leyla Ates, Moran Harari, and Markus Meinzer
}

\subsection{Introduction ${ }^{1}$}

Since 2011, the detrimental effects of spillovers on domestic as well as global stability have led the International Monetary Fund (IMF) to conduct extensive analysis of their widespread impact. The resulting reports have aimed to encourage discussion at multilateral forums in order to foster policy attention and multilateral dialogue. To begin with, these reports focused on the external effect of the world's five largest economies, namely, China, the Euro Area, Japan, the United Kingdom and the United States (IMF 2019a). Later on, the reports shifted focus towards a thematic approach and have brought key spillover issues to the forefront of the international agenda (IMF 2019b).

There are two principal reasons why international corporate taxation has featured so prominently in the IMF spillover reports. First, cross-border taxation has significance for macroeconomic stability at both the national and international levels (IMF 2013). Second, tax avoidance by multinationals has gained prominence in public

\footnotetext{
${ }^{1}$ Some passages of this article, predominantly in Sects. 10.2 and 10.3 , have been taken from a previously published report: Tax Justice Network (2019). The authors and the publisher of the original report kindly gave their permission for reuse of the text in this article.
}

\section{Ates $(\bowtie)$}

Faculty of Law, Altinbas University, Istanbul, Turkey

e-mail: leyla.ates@altinbas.edu.tr

\section{Harari}

Tax Justice Network, Tel Aviv, Israel

e-mail: moran@taxjustice.net

M. Meinzer

Tax Justice Network, Marburg, Germany

e-mail:markus@taxjustice.net 
discussion following the Lough Erne Declaration from the G-8 summit of 17-18 June 2013, which called countries to "change rules that let companies shift their profits across borders to avoid taxes" (G8 2013). Ultimately, the IMF defined international tax spillovers as "the impact that one jurisdiction's tax rules or practices has on others" in its landmark 2014 report (IMF 2014).

Moreover, the 2014 report established how a country's corporate tax system may generate macro-relevant effects on other countries via two channels: "base spillovers" and "strategic spillovers" (also see Crivelli et al. 2016; Cobham and Janský 2017). The "base spillover" concept includes changes in taxable profits "in reflection of both real responses (through investment and the like) and profit-shifting responses (affecting, loosely speaking, only where profits are booked for tax purposes)" (IMF 2014). The "strategic spillover" effect refers to " "tax competition' in its broadest sense-most obviously in the potential form of a 'race to the bottom', as countries respond to lower corporate income tax (CIT) rates elsewhere by reducing their own rates" (IMF 2014).

This approach acknowledges that for states, "tax rules and tax rates have become, to a large extent, the currency of tax competition" (Dagan 2018). By maintaining lower statutory corporate tax rates than other states, restricting the scope of or inserting gaps and loopholes into corporate tax rules, pushing down withholding rates in double tax treaties and dispensing with anti-avoidance and transparency policies, jurisdictions unwillingly enable or wittingly incite tax spillovers from other countries. In each of these policy areas, jurisdictions can choose to engage in more or less aggressive tax poaching policies, an approach echoing the notion that "virtually any country might be a 'haven' in relation to another" (Picciotto 1992). As a result, each jurisdiction's policies can be placed on a spectrum of corrosiveness of its corporate tax rules, resulting in a more nuanced picture than the established binary "blacklists" of corporate tax havens (Meinzer and Knobel 2015; Meinzer 2016; Cobham et al. 2015; Lips and Cobham 2018; Mosquera Valderrama 2019).

The focus of this article is on a new empirical legal dataset that makes a novel contribution to cross-border spillover analyses by conducting a transparent legal analysis of a comprehensive set of plausible negative and positive spillover pathways in domestic corporate income tax systems. While extant international tax spillover analyses explore a limited set of spillover pathways or indicators (Lusiani and Cosgrove 2017; Christensen 2018), the new Corporate Tax Haven Index (CTHI) includes 20 key tax spillover indicators under 5 categories and assesses 64 countries' tax systems ${ }^{2}$ to identify which policies they should consider for corporate tax reform in order to mitigate cross-border tax spillovers (Tax Justice Network 2019).

\footnotetext{
${ }^{2}$ The list of countries covers all EU-27 member states and the United Kingdom, 12 EU territories (Anguilla, Bermuda, British Virgin Islands, Cayman Islands, Gibraltar, Guernsey, Isle of Man, Jersey, Turks and Caicos Islands, Aruba, Curacao and St. Maarten), 9 African countries (Botswana, Gambia, Ghana, Kenya, Liberia, Mauritius, Seychelles, South Africa and Tanzania) and 14 jurisdictions selected based on their role, established in the research literature, as significantly misaligned with other jurisdictions, and/or anecdotal evidence that the jurisdiction may be playing an important role in international corporate taxation (Andorra, Liechtenstein, Monaco, San Marino,
} 
This article particularly aims to highlight international corporate tax spillovers pathways in the 27 European Union (EU) member states' domestic tax laws, regulations and documented administrative practices, especially in the context of developing countries. As such, out of the 64 countries assessed by the CTHI, the article will focus on the $27 \mathrm{EU}$ countries and compare them to the 4 lower-income countries and lower middle-income countries covered by the CTHI (Gambia, Liberia, Tanzania, Ghana and Kenya), all of which are in the African region and will be referred to in this article as "developing countries".

The article limits its scope to domestic tax rules and practices that may create negative spillovers. ${ }^{3}$ It is based on CTHI data and indicators, which categorise domestic negative spillover into two categories. Section 10.2 of the article discusses the "lowest available corporate income tax rate" (LACIT) indicator, consisting of the first category of negative spillovers. From the widely used "highest statutory corporate income tax rate", it derives through legal analyses the lowest rate for active business income available to subsidiaries of large multinationals. Section 10.3 of the article discusses "loopholes and gaps", the second category of the CTHI comprising seven indicators. It analyses the availability of elements within this category such as preferential tax regimes, sector-specific carve outs of the corporate tax rate base, tax rate concessions, tax holidays and economic zones.

The negative spillover analysis of EU member states' regulations is of particular importance to developing countries. In 2008, as an essential means for combating cross-border tax evasion and to strengthen the fight against money laundering, the EU Economic and Financial Affairs Council (ECOFIN) introduced the standard of good governance in tax matters to be adopted in all international agreements with third countries without prejudice to their respective competences (Council of the European Union 2008). In 2010, as part of its communication to the European Parliament, the EU Commission stated that "the EU is seeking from all countries and in particular its partner countries, agreement on the basic cooperation principles of good governance in the tax area (transparency of the tax system, exchange of information and fair tax competition) that its Member States have already achieved" (European Commission 2010). Nonetheless, as our analysis will show, the EU rules and practices have so far failed to achieve fair tax competition for EU member states and for non-member countries. In fact, the current rules contribute to unfair tax competition in a way which harms developing countries the most. Given that the EU has already added texts regarding standards of good governance in tax matters to several trade, strategic and economic partnership agreements (Mosquera Valderrama 2019) and both parties to these agreements are bound to follow the agreement,

\footnotetext{
Switzerland, Singapore, USA, China, Hong Kong, Panama, Bahamas, Taiwan, United Arab Emirates, Lebanon, Macao).

${ }^{3}$ The positive spillover categories and the third category of negative spillover indicators of the CTHI on a country's tax treaty network and withholding rates are outside the scope of this article. For an article related to the positive spillovers categories, see Ates, L., Harari, M. and Meinzer, M. (2020). Positive spillovers in International Corporate Taxation and the European Union. Intertax, 48:4, 389-401.
} 
developing countries can use the standard of good governance in tax matters to demand EU countries take concrete measures on fairer tax practices by eliminating the negative spillovers emanating from their countries.

Furthermore, Article 208 of the Lisbon Treaty on the Functioning of the European Union, which entered into force on 1 December 2009, requires the EU to take into account "the objectives of development cooperation in the policies that it implements which are likely to affect developing countries" (EU 2008). Tax and transfer systems in developing countries are, in general, far less effective at reducing poverty and inequality than those of developed ones. If spillovers from corporate tax rules reduce the tax revenues from direct and progressive corporate income taxes in developing countries, poverty may be exacerbated by shifting the tax mix onto more indirect, regressive types of taxes (Lustig 2018; McNabb and LeMay-Boucher 2014). Considering the vital role of domestic resource mobilisation in achieving the Sustainable Development Goals (Crivelli et al. 2016), both the standard of good governance in tax matters and Article 208 of the Lisbon Treaty can be used as policy tools for developing countries in negotiating their tax matters with EU member states.

\subsection{LACIT}

The LACIT indicator derives from law-based corporate tax rates built on a transparent legal analysis of the corporate income tax framework of jurisdictions.

Several studies have identified a range of negative spillover effects as states compete to offer lower corporate income tax rates (Devereux et al. 2008; Klemm and Van Parys 2012; Crivelli et al. 2016). Moreover, these studies also point out a discrepancy between statutory corporate tax rates and the legally documented lowest corporate tax rates available in a jurisdiction (Abbas and Klemm 2013). To address this issue, the CTHI calculates a jurisdiction's LACIT differently from existing datasets of statutory corporate income tax rates.

The LACIT indicator is determined by three steps, only the first of which relies on (top) statutory corporate income tax rates for $2018^{4}$ as reported in the Organisation for Economic Co-operation and Development (OECD) tax database (OECD 2019), or in the KPMG Corporate Tax Rates Table and International Bureau for Fiscal Documentation (IBFD) Tax Research Platform for jurisdictions not covered by the OECD (KPMG 2019; IBFD 2019).

In the second step, the CTHI reviews the statutory rates and corrects these if necessary. Corrections are made if there are lower corporate income tax rates available according to the size of the business, the economic sector in which the

\footnotetext{
${ }^{4}$ The CTHI was launched on May 2019, and it took into account the 2018 tax rates for country assessments. The rates will be refreshed every 2 years with each edition of the CTHI.
} 
business operates $^{5}$ or the subnational divisions (states/cantons/communes) where the business is tax resident. ${ }^{6}$ In this regard, the CTHI adjusts Germany, Italy and Portugal's statutory tax rates due to the rates offered in their subnational regions. For example, the statutory corporate tax rate of Portugal is calculated by adding the general corporate tax rate of $21 \%$ to a state surtax of $9 \%$ and a local surcharge of up to $1.5 \%$ of the taxable profit (OECD 2019). But given that 102 municipalities out of the total 304 municipalities in the country do not impose the local surcharge of up to $1.5 \%$ (IBFD 2019), the CTHI ignores this statutory rate for this indicator and sets $30 \%$ as the lowest available corporate income tax in Portugal.

In the third step, the CTHI analyses, and adjusts if necessary, the tax rates if treatment differs in any of the following ways: distribution or retention of profits, selection of a particular type of company, sourcing profits from inside or outside the jurisdiction (territorial tax regimes) or upon issuance of unilateral tax rulings. Several cases of adjustment to the EU member states' statutory tax rates are particularly relevant to this matter.

For example, Malta, with a statutory corporate income tax rate ordinarily reported at $35 \%$ (IBFD 219), operates a full imputation system. This system ensures that almost all tax paid is refunded upon distribution of profits and thus a much lower corporate income tax rate applies. ${ }^{7}$ As a result of Malta's imputation system, the CTHI sets Malta's LACIT at 5\% and not at the often reported statutory rate of $35 \%$. A similar result can be achieved when the tax is imposed only upon distribution. For example, in both Latvia and Estonia, the profits of resident companies are taxed only upon distribution (IBFD 2019). Thus, given that a company which chooses not to distribute its profits does not pay any corporate income tax, the CTHI assesses Latvia's and Estonia's LACIT at zero.

Over and above these, the statutory corporate tax rates of Belgium, Luxembourg, Ireland and Netherlands have been adjusted based on findings from the state aid

\footnotetext{
${ }^{5}$ For more details on the economic sector treatment, see Sect. 10.3.4 on "Sectoral Exemptions".

${ }^{6}$ However, differing corporate income tax regimes with lower rates which are available in a specifically designated economic zone or in a subnational region is disregarded for this indicator as the CTHI analyses and assesses it in the tax holidays and economic zones indicator under the loopholes and gaps group; see Sect. 10.3.5.

${ }^{7}$ KPMG notes on Malta: "A fundamental pillar of Malta's tax system is its full imputation tax system which completely eliminates the economic double taxation of company profits. Shareholders in receipt of dividends are entitled to a tax credit equal to the tax borne on the profits out of which the dividends are paid. Since the tax rate of $35 \%$ applicable to companies is also the highest tax rate in Malta, shareholders will not suffer any additional tax on the receipt of dividends. Where the shareholder's tax on the dividend is lower than $35 \%$, the amount by which the tax credit exceeds the tax on the dividend will be refunded to the shareholder if the shareholder includes the dividend in his tax return. Upon a distribution of profits by a company registered in Malta (i.e. a company resident in Malta or a non-resident company with a branch in Malta), its shareholders may claim partial tax refund. The most common tax refund is of $6 / 7$ ths, i.e. $30 \%(6 / 7$ ths of $35 \%)$ of the taxable profits. Where no double taxation relief has been claimed, the effective tax suffered in Malta on distributed profits will be 5\%. Malta's tax refunds system is applicable to both resident and non-resident shareholders in respect of the tax borne on profits derived from both domestic and international activities" (KPMG 2018).
} 


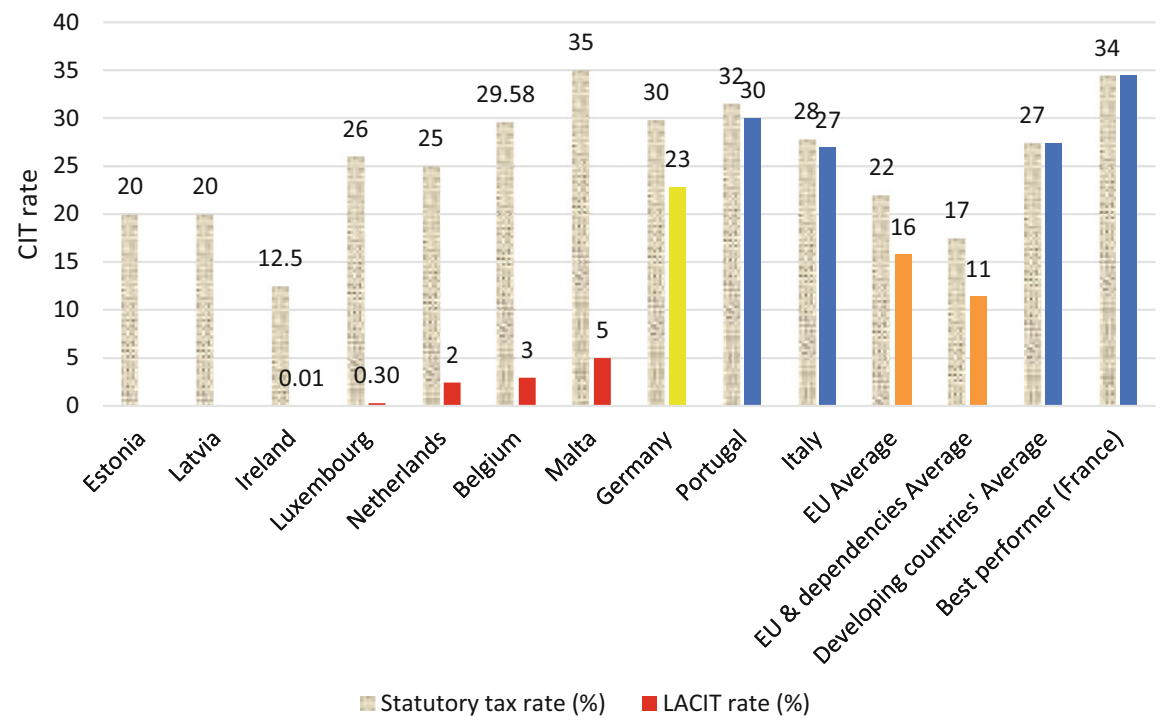

\begin{tabular}{|c|c|c|c|}
\hline Maximum Risk & $\begin{array}{c}\text { LACIT Rate } \\
\text { between } \\
\text { LACIT Rate } \\
\text { between 0\%-8.8\% }\end{array}$ & $\begin{array}{c}\text { LACIT Rate } \\
\text { between } \\
17.5 \text { and } 26.2 \%\end{array}$ & $\begin{array}{c}\text { Minimum Risk } \\
\text { LACIT Rate } \\
\text { above } 26.3 \%\end{array}$ \\
\hline
\end{tabular}

Fig. 10.1 Statutory rate v. LACIT (most misleading jurisdictions and average of regions)

investigations by the European Commission. For example, in Luxembourg, based on a binding agreement with the Luxemburg tax administration, the ENGIE Group was found to have been paying $0.3 \%$ instead of $26 \%$ corporate income tax on its profits. This rate is based on the commission's conclusion on 19 June 2018 that two sets of tax rulings issued by Luxembourg to two companies in the ENGIE Group endorsed an inconsistent treatment of the same transaction both as debt and as equity and enabled the Group to avoid paying any tax on $99 \%$ of the profits generated by two of its subsidiaries (European Commission 2018). The rulings artificially lowered ENGIE's tax burden, and for about a decade, the Group's effective tax rate on these profits in Luxembourg was less than 0.3\% (European Commission 2018). Because Luxembourg does not publish all tax rulings online, it is impossible to check if similar arrangements remain in place today. Unless proven to the contrary, the CTHI assumes therefore that large multinational companies can enter into tax deals with Luxembourg tax administrations lowering their corporate income tax rate to $0.3 \%$ on recorded profits.

Figure 10.1 provides a summary of the deviations between the statutory corporate tax rate and the LACIT. Estonia, Latvia, Ireland and Luxemburg offer a zero or almost $0 \%$ lowest available corporate income tax which is much lower than the statutory tax rate of $20,12.5,20$ and $26 \%$, respectively. Similarly, the Netherlands, Belgium and Malta offer $5 \%$ or less, which is also much lower than the statutory tax 
rate of $29.58,35$ and $25 \%$, respectively. France is the best performer with its highest tax rate $(34 \%)$ identical to the LACIT.

The data reveals three important aspects of EU corporate tax policy that are relevant for spillovers impinging on the domestic revenue mobilisation efforts of developing countries. First, the discrepancy between the statutory corporate income tax rates and the LACIT is high in the EU (the EU average statutory tax rate was $22 \%$ in 2018 (European Commission 2019) compared with an average LACIT of only $16 \%$ ). In comparison, the developing countries' average statutory tax rate is much higher, $27 \%$, with no gap whatsoever between their statutory and LACIT rates. This suggests that the EU is engaging in a hidden race to the bottom in corporate tax rates, among others, through the backdoor of secretive and dubious tax rulings. Second, when combining the EU-controlled dependencies, the average LACIT falls even further to $11 \%$, reinforcing the notion of an indirect tolerance or acceleration of the race to the bottom in corporate taxation. This suggests that the EU's insistence on good governance in tax practices is hypocritical. Third, the steep gap between the LACIT rates of EU members and its dependencies on the one hand, and developing African countries on the other hand, suggests substantial tax spillover risks emanating from the EU's relatively lower rates, which may entice inward profit shifting and lead to base erosion in developing countries.

\subsection{Loopholes and Gaps}

Comparison of the EU member states and developing countries' results across the seven indicators comprising the "loopholes and gaps" category is revealing. As shown in Fig. 10.2 and explained in more detail below, developing countries perform better on average than EU member states on the indicators for capital gains taxation, sectoral exemptions, fictional interest deduction, foreign investment income treatment and patent boxes. On the other hand, developing countries have higher haven scores on average for two indicators: loss utilisation, which assesses the availability of unrestricted loss carry-forward and loss carry-backward, and tax holidays and economic zones.

\subsubsection{Foreign Investment Income Treatment}

This indicator assesses whether a jurisdiction includes worldwide capital income in its corporate income tax base and if its domestic law grants unilateral tax credits for foreign tax paid on certain foreign capital income. The types of capital income included are interest, royalty and dividend payments from a related or independent company.

In the current international tax setting, the problem of overlapping tax claims (double taxation) of source and residency countries are addressed in unilateral and/or 


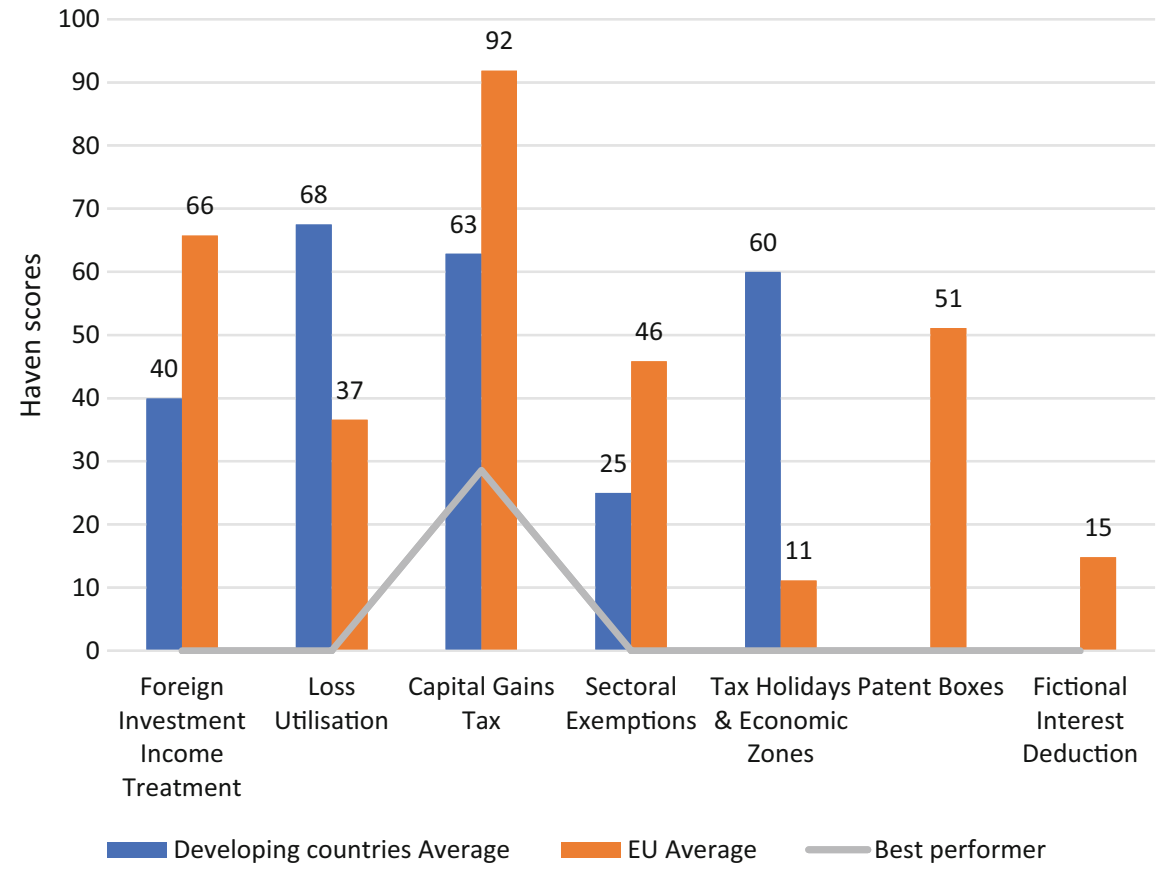

Fig. 10.2 Comparison of loophole and gap indicators for developing countries and EU member states

bilateral ways. In most cases, it is a myth that bilateral treaties are needed to provide relief from double taxation (Dagan 2000). The home countries of investors or multinational companies usually offer unilateral relief from double taxation to support outward investment. They do this primarily through exempting foreign income from tax liability at home (the exemption method) or granting credit for the taxes paid abroad on the taxes due at home (the credit method). There is a third mechanism called "deduction" which is sometimes used to offer relief from double taxation. However, the deduction method does not offer full relief from double taxation. It allows the deduction of any taxes paid abroad from foreign income (e.g. as a business expense) before including this income in the domestic tax base.

Where countries, especially capital exporting ones, refrain from providing unilateral relief or only provide deduction of foreign taxes from the domestic tax base, they contribute to the problem of double taxation and thus indirectly exert pressure on capital importing countries to conclude bilateral treaties with the other country. However, bilateral treaties are expensive to negotiate and often impose a cost on the weaker negotiating partner which is frequently required to concede lower tax rates in return for the prospect of more investment (Neumayer 2007; McGauran 2013; Hearson 2016). In turn, these treaties can expose capital importing countries to negative spillovers. 
In addition, with more than 3500 double tax treaties currently in operation, the system has become overly complex and permissive, encouraging corporations to engage in profit shifting, treaty shopping and other practices at the margins of tax evasion. This is the context in which the CTHI reviews unilateral mechanisms to avoid double taxation in the first place. However, not all such mechanisms are equally useful.

When using a unilateral exemption mechanism to exempt all foreign income from liability to tax at home, the country of residence may force other jurisdictions to compete for inward investment by lowering their tax rates (IMF 2013). Because investors or corporations will not need to pay any tax back home on the profit they declare in the foreign jurisdiction (source), they will look more seriously at the tax rates offered. This encourages countries to reduce tax rates on capital income paid to non-residents, such as withholding taxes on payments of dividends and interest.

In contrast, a unilateral tax credit mechanism does not incentivise the host countries of investments to lower their tax rates (IMF 2013). A tax credit system requires that income earned abroad must be taxed at home as if it was earned at home, unless it has already been taxed abroad. In the latter case, the effective amount of tax paid abroad on the income will be subtracted from the corresponding amount of tax due at home. Therefore, for an investor the tax rate in a host country is no longer relevant to her investment decisions. Countries wishing to attract foreign investment will not feel compelled to lower their tax rates in the hope of increasing their stock of foreign investment.

Thus, a jurisdiction that provides no unilateral relief, or only deducts foreign tax paid or effectively exempts foreign income from domestic taxation (through a territorial tax system, exemptions for specific payments or specific legal entities, deferral rules and zero or nil tax rates), creates a pathway for substantial negative spillover effects. On the other hand, a jurisdiction that grants a unilateral tax credit for some or all types of capital income payment scenarios limits the possibility for negative spillovers.

All EU member states promote negative spillovers by creating pathways through their treatment of foreign investment income. As a result of the EU's ParentSubsidiary Directive (Council Directive 2011), member states must either implement the exemption method or allow a unilateral credit for taxes levied on the level of the subsidiary and lower-tier companies to eliminate economic double taxation of cross-border intercompany dividends (Kofler 2012). Other than Ireland, all member states implement the exemption method. While some member states restrict this negative spillover pathway only to cross-border intercompany dividends (Bulgaria, Denmark, Germany, Greece, Poland and Portugal), others, including Ireland, create negative spillover pathways for other income scenarios as well. Several states create substantial risk by providing no unilateral relief and/or deduction for foreign tax paid and/or effectively exempting foreign income from domestic taxation for all income scenarios (Czech Republic, Estonia, France, Latvia, Luxembourg, Malta, Netherlands, Romania and Slovakia). Other member states limit the risks of negative spillovers by incorporating three income scenarios into their legislative frameworks (Belgium, Cyprus, Hungary, Ireland and Spain) or by introducing only two such 
treatments (as in the cases of Austria, Croatia, Finland, Italy, Lithuania, Slovenia and Sweden).

Compared with EU countries, three (Tanzania, Gambia and Ghana) out of the five developing countries covered by the CTHI received zero haven scores as they only allow for unilateral tax credits. Kenya, however, exempts foreign investment income in the form of dividends from its corporate tax base, and Liberia exempts such income in all three forms (dividends, royalties and interest). Given the incentive that tax exemption of foreign income provides for ruinous tax wars and negative spillovers, the fact that none of the EU countries receive zero tax haven scores indicates the significant risks for negative spillovers they create, including towards developing countries.

\subsubsection{Loss Utilisation}

The loss utilisation indicator looks at whether a jurisdiction provides loss carrybackward and/or unrestricted loss carry-forward for ordinary and trading losses.

The basic rationale behind the loss carryover rules is income averaging. Annual tax accounting systems are a main feature of modern income taxation. Income tax is calculated and charged on the income earned in the preceding fiscal year, which consists of 12 consecutive months. However, this system involves an intrinsic unfairness: "taxpayers whose incomes fluctuate from year to year should receive tax treatment equivalent to those with stable incomes" (Romano and Campisano 1981). To eliminate this intrinsic unfairness, countries provide tax relief on profits to reflect losses. Losses may be carried forward and set off against future profits and/or carried backward and relieved against profits in earlier or subsequent years.

However, companies might use losses as an aggressive tax planning tool by increasing or accelerating tax relief on their losses. Unrestricted loss carry-forward and backward thus enables profit shifting, investment round tripping and corporate (re)structuring for tax avoidance purposes (OECD 2011). ${ }^{8}$ To avoid abuse of such provisions by multinational companies, jurisdictions generally place limits on the time and value of loss carry-forward rules (OECD 2011). On the other hand, a loss carry-backward provision has more severe impacts on reducing government budgets

\footnotetext{
${ }^{8}$ For example, the use of artificial losses to minimise tax has been a core element of Apple's tax strategy in Ireland. In 2015, the artificial inflation of debt and a multibillion-dollar purchase of Apple's own intellectual property generated billions in recognised losses for Apple's subsidiary in Ireland (Coffery 2018). In other words, Apple Ireland borrowed heavily to purchase Apple's intellectual property from an Apple subsidiary tax resident in Jersey (which applies nearly zero tax). As a result, Apple Ireland had billions in deductible interest payments, billions in deductible intellectual property purchase expenses and billions in capital allowances, enough to write off all profits from European sales for years. Similarly, Apple's offshore entity in Jersey earned billions from the sale of intellectual property and interest repayments which went untaxed (Christensen and Clancy 2018).
} 
and is more difficult to administer than carry-forward provisions (OECD 2011). Thus, a jurisdiction that provides loss carry-backward or unrestricted loss carryforward rules creates pathways for negative spillovers.

To varying degrees, all EU member states other than Estonia, Latvia, Poland and Portugal promote negative spillover risk through loss utilisation rules. While Ireland and Sweden create substantial risk by providing loss carry-backward and unrestricted loss carry-forward, some member states reduce the risk only slightly by introducing a limitation to loss carry-forward while permitting unrestricted loss carry-backward (as in the cases of France, Germany, the Netherlands and the United Kingdom). Other member states have not introduced loss carry-backward at all. However, they still create risk by applying unrestricted loss carry-forward rules (Austria and Malta) or restricted loss carry-forward rules but not for up to 5 subsequent years and without an annual ceiling such as a fixed monetary ceiling and/or a percentage of taxable earnings for subsequent years.

Compared with EU countries, developing countries' average haven score for this indicator is significantly higher (68 as opposed to 37 for EU countries), predominantly due to the relevant policies of Kenya and Tanzania. In Kenya, losses for every sector can be carried forward without an annual ceiling for at least 9 years, and backward, allowing companies from the petroleum exploration industry to reduce their tax bill, for example, through unfavourable intra-group trades. The fact that developing countries allow for a more flexible loss utilisation policy indicates the risks for revenue losses in developing countries as well as for negative spillovers. The reasons for the higher risks of developing countries' loss utilisation policies likely lie in the lack of coverage of their potential negative consequences to date.

\subsubsection{Capital Gains Taxation}

This indicator measures the extent to which a jurisdiction taxes corporate capital gains arising from the disposal of domestic and/or foreign securities (i.e. shares and bonds). As such, it assesses the lowest available tax levied on corporate capital gains, applicable to large for-profit corporations which are tax resident in the jurisdiction.

By purchasing and holding assets through intermediary companies in jurisdictions with no or low capital gains taxation, the corporate income tax and capital gains tax systems of any jurisdiction can be easily circumvented. Therefore, the availability of jurisdictions with low or no capital gains taxation jeopardises the tax base of other jurisdictions and creates negative tax spillover effects similar to those of the LACIT indicator. ${ }^{9}$ The lower these rates become, the greater this spillover effect becomes. For example, the Paradise Papers revealed how US Yale University had contracted with offshore law firm Appleby to invest US\$100 million in India, thereby avoiding the payment of capital gains tax in both India and Mauritius

\footnotetext{
${ }^{9}$ See Sect. 10.2.
} 
(Yadav 2017). Not long after, in 2016, India successfully renegotiated its double tax treaty with Mauritius to require from 2017 onwards taxation of capital gains at the source (i.e. in India at Indian tax rates) and no longer in the residence jurisdiction of the investor (i.e. Mauritius nil capital gains tax). This change resulted in a steep decline of equity direct investment from Mauritius in India in subsequent years (Chowdhary 2019).

Twenty EU member states offer a zero or almost $0 \%$ lowest available corporate capital gain tax rate (Belgium, Cyprus, Czech Republic, Estonia, Finland, Germany, Greece, Ireland, Italy, Latvia, Lithuania, Luxembourg, Malta, Netherlands, Portugal, Romania, Slovakia, Spain, Sweden and the United Kingdom). In contrast, out of the five developing countries, only Kenya offers the lowest available capital gains tax rate of $0 \%$. This is because an exemption applies for domestic securities with shares listed on the Nairobi Securities Exchange and gains from the disposal of foreign securities are not taxable in Kenya because of its territorial tax system. Gambia is the best performer among both the EU and the assessed developing countries with a lowest available corporate capital gain tax rate of $25 \%$. In light of this, the fact that the vast majority of EU countries taxes capital gains at zero or almost $0 \%$ is striking and provides yet more profound evidence for the negative spillover risks they pose to other countries.

\subsubsection{Sectoral Exemptions}

This indicator analyses provisions where companies engaging in a specific activity are accorded a tax rate that is lower than the lowest available corporate tax rate usually applicable by default to any economic activity, without being subject to cost or expenditure requirements. If the lower rate is zero, the CTHI considers the exemption "full", and otherwise, the lower rate will constitute a "partial" exemption. ${ }^{10}$ Lower rates and narrower tax bases are treated as equivalent.

The CTHI focuses on tax reductions that are available to corporations that merely engage in a specific economic activity or are licensed or registered under a specific regime. These incentives are particularly harmful because it is much easier for multinational corporations to allocate profits to a tax-exempt company if the exemption regime does not ensure that the exemption applies to income resulting from domestic economic activity. By contrast, cost-based incentives are meant to ensure

\footnotetext{
${ }^{10}$ This indicator potentially overlaps with the indicator of LACIT, and the categorisation depends on the question of degree. If a country has these reductions or exemptions in enough sectors (four or more full exemptions, or eight or more partial exemptions), it is considered also under the LACIT, which has a higher weighting in the CTHI. Likewise, if a country has a $0 \%$ statutory tax rate, then any sector or activity would also have a $0 \%$ tax rate, resulting in a haven score of 100 (highest tax avoidance risk). In addition, this indicator excludes cases of exemptions resulting from a patent box regime or exclusively relating to capital gains. These are covered in Sects. 10.3.6 and 10.3.3, respectively.
} 
that the tax incentive applies only to companies effectively engaged in the domestic economy, by investing in fixed assets, hiring employees or supporting research and development.

Indeed, the IMF differentiates between these two types of incentives and indicates the harmfulness of profit-based as opposed to cost-based incentives. In its 2014 report, the IMF emphasises that cost-based incentives "[...] may generate investments that would not otherwise have been made [...]", whereas profit-based incentives tend to "[...] make even more profitable investment projects that would be profitable, and hence undertaken, even without the incentive" (IMF 2014). Moreover, incentives providing full tax exemptions often create an additional risk factor, in cases where non-taxable companies are not required to submit tax returns or other regulatory filings.

Among the EU member states, only Lithuania, Poland, Romania, Slovakia and Sweden pose almost minimum levels of negative spillover risk. Estonia and Latvia create maximum risk by effectively applying permanent exemptions in all economic sectors, ${ }^{11}$ whereas the risk profiles of other jurisdictions lie somewhere between these.

Out of the 64 researched jurisdictions, 10 jurisdictions apply no or zero corporate tax, 5 others present permanent exemptions in all economic sectors and a further 4 jurisdictions apply a wide range of harmful exemptions covering several economic sectors. Together, nearly $30 \%$ of the assessed jurisdictions offer widespread profitbased tax exemptions in all or nearly all economic sectors. Among these 19 jurisdictions, more than $70 \%$ are EU member states (Estonia and Latvia) or EU-dependent jurisdictions (UK dependencies of Anguilla, Bahamas, Bermuda, British Virgin Islands, Cayman Islands, Guernsey, Isle of Man, Jersey, Turks and Caicos Islands and Montserrat and the Netherlands' dependency of Aruba). ${ }^{12}$

An important finding from Fig. 10.3 is that profit-based exemptions are most widespread in passive investment sectors and the related banking and insurance sector. Furthermore, European Union members are most responsible for offering these. In both real estate and financial investment, $48 \%$ of EU countries offer full exemptions and $19 \%$ offer partial tax exemptions, whereas among the five developing countries only $30 \%$ present full exemptions and $10 \%$ partial exemptions. In the banking and insurance sector, a similar mismatch between EU countries and developing countries can be observed (EU27, 22\% full exemptions, 15\% partial exemptions; developing countries, $0 \%$ full exemptions, $20 \%$ partial exemptions). The widespread exemption of these types of activities results in spillover risks faced by

\footnotetext{
${ }^{11}$ Estonia's and Latvia's LACIT is zero because of the retention/distribution adjustment we are making in step 3 of the LACIT calculation (discussed under LACIT in Sect. 10.2). Since both countries' LACIT is zero, this applies to all economic sectors.

${ }^{12}$ Among the non-EU jurisdictions, the United Arab Emirates applies no or zero corporate tax; Monaco and Mauritius effectively apply permanent exemptions in all economic sectors; the Lebanon, Panama and Singapore apply a very wide range of harmful permanent exemptions, covering several economic sectors.
} 


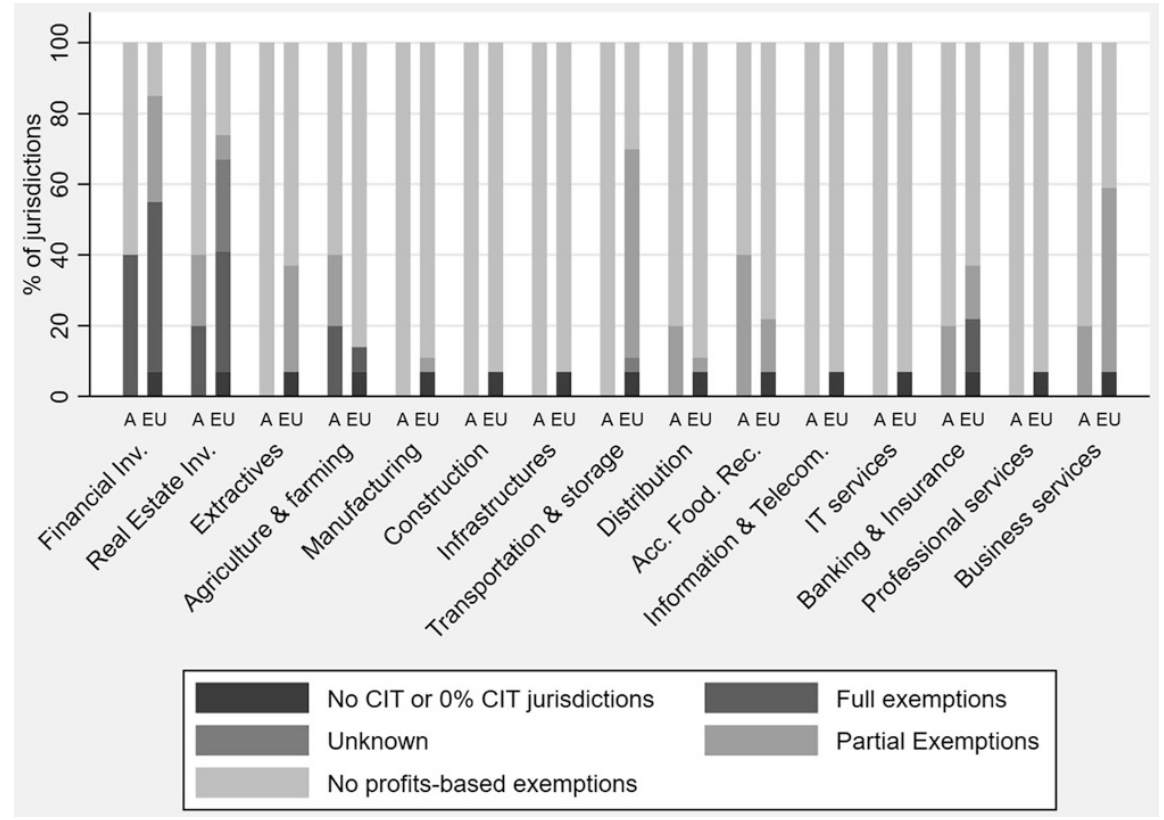

Fig. 10.3 Frequency of sectoral tax exemptions in 15 economic sectors ( 2 investment and 13 active business sectors) in 5 African (A) developing countries and 27 EU member states. Source: Author's own analysis based on CTHI data (The data presented in Fig. 10.3 was collected for CTHI 2019 but was adjusted subsequently. This adjustment was made because the limited coverage of tonnage tax regimes in the IBFD database became evident after consulting other legal data sources and domestic laws. This led to adjustments in sectors affected by such regimes (principally transportation and storage and business services). Moreover, the mere existence of a tonnage tax regime is now considered a partial exemption in the transportation and storage sector, in line with the treatment of other alternative regimes in Haven Indicator 5 of the CTHI) and based on Millán-Narotzky et al. (2020), with support from Lucas Millán-Narotzky and Miroslav Palanský

developing countries not only directly through profit shifting and asset management relocation but also indirectly by facilitating financialisation processes.

\subsubsection{Tax Holidays and Economic Zones}

This indicator assesses whether and to what extent a jurisdiction provides timebound or geographically confined incentives consisting of a tax rate that is lesser than the lowest available corporate tax rate usually applicable in this jurisdiction. These include temporary tax holidays, partial exemptions on corporate income tax and capital gains tax and special tax incentives (temporary or permanent) given to 


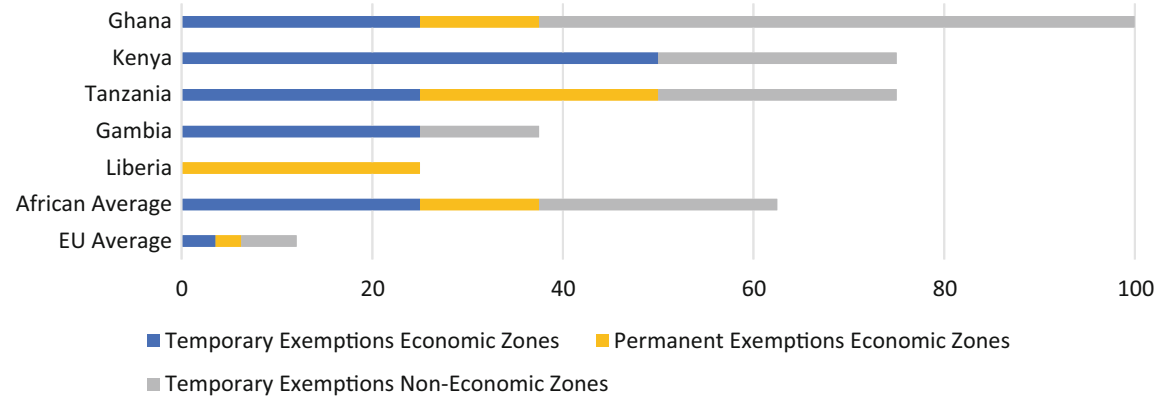

Fig. 10.4 Tax holidays and economic zones' subcomponents

companies located in designated economic zones. ${ }^{13}$ Similar to the preceding indicator, only "profit-based" tax exemptions are assessed because of their particular relevance to negative spillovers (IMF 2015).

Geographically confined tax incentives are usually granted as part of a country's goals to attract FDI, develop disfavoured or rural regions or certain sectors, increase government revenues, encourage skills upgrading and innovation and improve the productivity of domestic enterprises (Zeng 2010). However, the available evidence shows that tax incentives are often ineffective in attracting new greenfield FDI, especially in developing countries (Klemm and Van Parys 2012). Investment climate surveys for low-income countries show that tax incentives do not exert a decisive influence on investment decisions. Rather, investors are more interested in good infrastructure, an educated labour pool, the rule of law and macroeconomic stability. Evidence already suggests that providing geographically confined tax incentives imposes pressure on policymakers to provide the same benefits to other geographic areas, increasing revenue loss and social distortions (Keen and Mansour 2009). Moreover, free trade zones may be vulnerable to illicit activity and be abused through transfer pricing strategies given typically weak enforcement of financial regulations, lack of transparency and inadequate customs control (FATF and EGMONT 2013; FATF 2010).

Among EU member states, only France poses maximum risk by temporarily offering one partial and three full exemptions in non-economic zones and a full exemption followed by a partial exemption for companies in economic zones (IBFD 2019), whereas the other member states pose almost minimum risks, except Lithuania. Lithuania has several economic zones where a standard tax inventive regime temporarily applies a full exemption followed by a partial exemption for qualifying companies which is accessible pursuant to the criteria established separately for each economic zone (IBFD 2019).

As presented in Fig. 10.4, compared with EU countries, developing countries have on average considerably higher haven scores on this indicator. In Kenya,

\footnotetext{
${ }^{13}$ An economic zone is commonly defined as a delimited area that is physically secured and has a single administration, separate customs area and streamlined procedures (Rao et al. 2008).
} 
Ghana and Tanzania in particular, special tax incentives in a limited geographical area-such as in free ports, export processing zones and special economic zones-or special tax holidays available over a set period of time result in high haven scores. Ghana, for example, offers several time-bound tax holidays that reduce the statutory corporate income tax rate of $25 \%$ significantly; as such, rural banks, tree crops and venture capital financing companies are all taxed at $1 \%$ for the first 10 years, while cocoa by-production processing, fisheries and cash crops are taxed at $1 \%$ for the first 5 years.

As part of their efforts to attract foreign direct investment from foreign companies, developing countries offer a wide range of high-risk profit-based tax incentives conducive to lower tax revenues and spillover risks. African countries on average offer three profit-based tax incentives, such as economic zones and tax holidays, for every cost-based tax incentive. In comparison, European countries on average offer a near one-to-one ratio of tax incentive types, indicating a greater awareness in the EU of the risks profit-based tax incentives represent (Meinzer et al. 2019).

\subsubsection{Patent Boxes}

This indicator measures whether a jurisdiction offers preferential tax treatment for income related to intellectual property rights (e.g. patent boxes). A preferential tax treatment for intellectual property rights usually takes the form of either special costbased tax incentives or profit-based tax incentives (e.g. lower tax rates). For this indicator, the CTHI only considers profit-based patent box regimes.

A patent box regime provides tax privileges for highly profitable businesses and enables cross-border profit shifting into these tax regimes, undermining the tax bases of jurisdictions elsewhere. The available evidence indicates that promises to spur innovation, tax revenues and growth through the introduction of patent boxes have failed to materialise. In contrast, available evidence suggests that patent box regimes are effective only in raising multinationals' share prices (CPB 2014; Guenther 2017; Gaessler et al. 2018).

While patent boxes in theory could increase tax revenues, ${ }^{14}$ the positive effects of an individual country's policy are likely to be eroded by the responses of other governments, which may include even more aggressive and corrosive tax policies. For many years, patent boxes have been used by multinational corporations to avoid taxation by shifting profits out of the countries where they do business and into a foreign country with a patent box regime, where the profits are taxed at very low levels or not at all. Research indicates that such profit shifting leads to misattribution

\footnotetext{
${ }^{14}$ Although a report published by the Centre for European Economic Research in 2013 claims that "In the larger of the countries, that have significant innovation bases, it is more likely that IP [intellectual property] boxes will lead to significant revenue losses. Empirical evidence that simulates the Benelux and UK IP Boxes finds that the increase in IP income locating in the countries is insufficient to outweigh the lower tax rate" (Evers et al. 2013).
} 
of economic activities, resulting in productivity slowdown (Guvenen et al. 2018). It also enables multinational companies to monopolise the market, while companies that lack the scale of the multinational corporations will be disadvantaged simply because they do not have the resources available to establish global structures which can allow them to avoid tax (Hwang 2018). Thus, a jurisdiction that has a patent box regime potentially creates a substantial negative spillover risk. When the jurisdiction makes this regime available with OECD nexus constraints that allow taxpayers to benefit only if they can link the income that stems from the intellectual property to expenditures incurred (OECD 2015), it might reduce negative spillovers. However, the modified nexus approach allows artificial increases of qualifying expenditures (Sanz Gomez 2015) and requires using the arm's length price to determine related party acquisition costs (OECD 2015). Given the difficulty in determining an appropriate arm's length price for intellectual property and related royalty payments, this might lead to only a small reduction in negative spillovers, if any (Etter-Phoya et al. 2020).

Fifteen member states of the EU provide patent box regimes. At the time the CTHI research was conducted, nine member states failed to apply OECD nexus constraints (Belgium, Cyprus, Hungary, Ireland, Italy, Luxembourg, Malta, Netherlands, Portugal, Spain and the United Kingdom), ${ }^{15}$ whereas two of them operate under the OECD constraints (France and Slovakia). Since the patent box regimes of two member states (Greece and Lithuania) have not been subjected to annual monitoring by the EU (Council of the European Union 2018), the CTHI considers their spillover risk as unknown.

Comparing the haven scores of EU member states to those of the developing countries studied (see Fig. 10.2) is illuminating. None of the five developing countries applies a patent box preferential tax regime at all (haven scores of zero). As a result, it is evident again that the responsibility for creating the negative spillover risk through such regimes lies primarily with EU countries.

\subsubsection{Fictional Interest Deduction}

This indicator measures whether a jurisdiction offers fictional (notional) interest deduction to lower corporate income taxes.

Many tax systems around the world offer tax advantages for corporations to finance their investments by debt. As opposed to dividends, which are not deductible and are paid to shareholders after tax has been paid, interest payments on loans are

\footnotetext{
${ }^{15}$ Although these member states have replaced their regimes with a new regime which is available only with OECD nexus constraints, the grandfathering rules enable companies who entered the regime earlier to continue benefitting from the old harmful patent box regime until 31 December 2020 or 30 June 2021 (Council of the European Union 2018). Since the preferential regime has been available as of May 2019, the CTHI concludes this pathway is available for the purposes of this indicator.
} 
one of the many deductible costs a company can make for corporate tax purposes. The evidence indicates that this tax advantage for debt financing, known as debt bias, creates significant inequities, complexities and economic distortions (Chan 2011).

To mitigate the different tax treatments of debt and equity financing and to reduce the level of debt bias, some countries have introduced a fictional interest deduction regime. The term "fictional interest deduction" refers to fictitious interest expenses that companies and sometimes also permanent establishments are entitled to calculate annually on the amount of their total equity and deduct for tax purposes, in the same way that interest on loans is tax deductible. The amount that can be deducted from the taxable base is equal to the fictitious interest cost on the adjusted equity capital.

However, adopting a fictional interest deduction regime to neutralise the debt bias has significant drawbacks. The idea behind the fictional interest deduction regime is to apply an artificial interest deduction. Not surprisingly, such a fictitious vehicle may be vulnerable to tax abuse by multinational companies. And indeed, soon after the fictional interest deduction regime was introduced in Belgium, multinational companies used commonly applied techniques of abuse. Through double dipping, companies end up receiving two tax benefits: the tax deduction of interest paid on a loan and fictional interest deduction based on the capital increase with the funds made available by the loan. The latter includes artificially increasing equity through specific intra-group reorganisation (Peeters and Hermie 2011).

Additionally, other countries may decide in response to fictional interest deductions to lower their tax rates in an attempt to lure more multinationals to invest. This accelerates the race to the bottom in corporate taxation. Thus, a jurisdiction with a fictional interest deduction regime potentially creates a substantial negative spillover risk.

Among the 64 countries researched, only EU member states (with the exception of Liechtenstein) apply a fictional interest deduction rule. Belgium was one of the first countries to introduce a fictional interest deduction regime in 2005, and since then, other countries like Italy, Cyprus, Malta and Portugal have followed suit (Council of the European Union 2018; Hebous and Klemm 2018), albeit Italy has just abolished this pathway via its 2019 Budget Law (Deloitte 2019).

Similar to the precedent indicator on patent box regimes, not even one of the five developing countries allows for a fictional interest deduction rule, and several European countries in particular are responsible for the potential negative spillover risk towards other countries.

\subsection{Conclusions and Recommendations}

When a jurisdiction introduces a low statutory tax rate and restricts the scope of or inserts gaps and loopholes into its corporate tax system, it increases the likelihood of negative spillovers. The CTHI reviews a comprehensive set of negative and positive tax spillover indicators and assesses 64 countries' international corporate tax 
systems. Then, it converts this qualitative data into numerical data through a coding strategy. ${ }^{16}$ Each indicator is given a score between 0 (no harmful impact, zero corporate tax haven attributes) and 100 (full corporate tax haven attributes). The CTHI takes the average of these indicator scores to reach the Haven Score that points to the potential of a jurisdiction's tax system to create spillovers. ${ }^{17}$ When we compare the average haven score of all EU member states with the developing countries' average haven scores, the following conclusions can be drawn for negative spillover indicators:

First, the EU average LACIT rate $(16 \%)$ is much higher than the average of $27 \%$ among developing countries. However, the negative spillover risk considerably increases when the EU and their dependencies are considered as a whole (11\%). This suggests that the EU member states bear more responsibility for the "race to the bottom" in corporate taxation than developing countries (Etter-Phoya et al. 2020). Second, the EU average haven score for loopholes and gaps category (46) is higher than the average for developing countries (35). Nonetheless, out of the seven indicators included in this category, the EU scores considerably better than developing countries (11 vs. 60) for tax holidays and economic zones. This finding should be carefully considered by developing countries' governments, predominantly in light of available evidence suggesting the ineffectiveness of geographically confined tax incentives in attracting foreign direct investment, especially in developing countries (see Klemm and Van Parys 2012).

Overall, our analysis demonstrates that while the EU's level of responsibility for creating negative tax spillover risks is similar to that of OECD countries, it greatly exceeds the level of risk created by developing countries. As our evidence shows, EU member states should reform their tax systems in order to mitigate the negative spillover effects of their domestic tax rates and rules, both domestically, within the EU and externally, especially towards developing countries. By improving their haven scores in the two categories analysed in this article, EU member states could help achieve its Sustainable Development Goals by reducing the erosion of public revenues and supporting domestic resource mobilisation.

\footnotetext{
${ }^{16}$ To measure the intensity of spillover risks for the LACIT and capital gain taxation, the CTHI calculates a country's lowest available rate as a percentage of the highest observable corporate income tax rate of a democracy in order to determine the extent of tax avoidance risks which undermine democratic choices elsewhere. This rate is 35\% in the case of India for 2018. Then, the CTHI subtracts this number from 100. For example, when a jurisdiction has $25 \%$ as the lowest available rate, the haven score would be 100 minus the percentage of $25-35$, i.e. 28.6 . In the worstcase scenario, a country without income taxation has 0\% LACIT, and the haven score of this country would be 100 . That means this jurisdiction has the highest tax avoidance potential.

${ }^{17}$ It then combines the haven score with a quantitative component of the Global Scale Weight attributed to each jurisdiction that is based on an assessment of the size of each jurisdiction's share of the global total of foreign direct investment. The CTHI value, which determines a ranking, is calculated by multiplying the cube of the haven score with the cube root of the Global Scale Weight. The final result is divided through by 100 for presentational clarity. For the ranking of researched jurisdictions, see Tax Justice Network (2019).
} 
Acknowledgements The writing and research carried out for this chapter were part of the Combating Fiscal Fraud and Empowering Regulators (COFFERS) project (2016-2019). The COFFERS project unfolds as EU tax authorities transition to a new era in tackling tax abuse based upon policy innovation at the international and national levels. The COFFERS project has received funding from the European Union's Horizon 2020 research and innovation programme under grant agreement n. 727145. Special acknowledgement to Burcak Bal Yalcin, Lucas MillánNarotzky and Miroslav Palanský.

\section{References}

Abbas, S. M. A., \& Klemm, A. (2013). A partial race to the bottom: Corporate tax developments in emerging and developing economies. International Tax and Public Finance, 20, 596-617.

Ates, L., Harari, M., \& Meinzer, M. (2020). Positive spillovers in international corporate taxation and the European Union. Intertax, 48(4), 389-401.

Chan, N. T. L. (2011). Excessive leverage-Root cause of financial crisis. Retrieved March 31, 2019, from https://www.bis.org/review/r111215g.pdf

Chowdhary, A. M. (2019). Mauritius: India cracks down on a major tax evasion route. Retrieved June 26, 2020, from https://www.taxjustice.net/2016/05/24/mauritius-india-curbs-a-major-taxevasion-route/

Christensen, B. M. (2018). Stemming the spills: Guiding framework for undertaking national tax spillover analyses. Retrieved August 30, 2019, from https://actionaid.org/sites/default/files/ stemming_the_spills_online.pdf

Christensen, M. B., \& Clancy, E. (2018). Exposed: Apple's golden delicious tax deals. Is Ireland helping apple pay less than 1\% tax in the EU? Retrieved August 30, 2019, from https://www. guengl.eu/content/uploads/2018/06/Apple_report_final.pdf

Cobham, A., \& Janský, P. (2017). Global distribution of revenue loss from tax avoidance: Re-estimation and country results. UNU-WIDER Working Paper. 2017/55. Retrieved May 21, 2019, from https://www.wider.unu.edu/sites/default/files/wp2017-55.pdf

Cobham, A., Janský, P., \& Meinzer, M. (2015). the financial secrecy index: Shedding new light on the geography of secrecy. Economic Geography, 91, 281-303.

Coffery, S. (2018). Economic incentives: What apple did next. Retrieved May 21, 2019, from http:// economic-incentives.blogspot.com/2018/01/what-apple-did-next.html

Council Directive. (2011). 2011/96/EU of 30 November 2011 on the common system of taxation applicable in the case of parent companies and subsidiaries of different Member States [2011] OJ L 345.

Council of the European Union. (2008). 2866th council meeting economic and financial affairs. 8850/08 (Presse 113), 22-23 (Press Release 14 May 2008). Retrieved March 25, 2019, from https://www.consilium.europa.eu/ueDocs/cms_Data/docs/pressData/en/ecofin/100339.pdf

Council of the European Union. (2018). Code of Conduct Group (Business Taxation): Overview of the preferential tax regimes examined by the Code of Conduct Group (Business Taxation) since its creation in March 1998. Retrieved March 25, 2019, from http://data.consilium.europa.eu/ doc/document/ST-9639-2018-REV-2/en/pdf

CPB Netherlands Bureau for Economic Policy Analysis. (2014). A study on $R \&$ \& tax incentives: Final report. Luxembourg: Office for Official Publications of the European Communities.

Crivelli, E., De Mooij, R., \& Keen, M. (2016). Base erosion, profit shifting and developing countries. FinanzArchiv: Public Finance Analysis, 72(3), 268-301.

Dagan, T. (2000). The tax treaties myth. New York University Journal of International Law and Politics, 32, 939-996.

Dagan, T. (2018). International tax policy: Between tax competition and cooperation. Cambridge: Cambridge University Press. 
Deloitte. (2019). Changes to tax incentives under 2019 budget law. Retrieved September 2, 2019, from https://www.taxathand.com/article/10903/Italy/2019/Changes-to-tax-incentives-under2019-budget-law

Devereux, M. P., Lockwood, B., \& Redoano, M. (2008). Do countries compete over corporate tax rates? Journal of Public Economics, 92, 1210-1235.

Etter-Phoya, R., Lima, S., \& Meinzer, M. (2020). Tax base erosion and corporate profit shifting: Africa in international comparative perspective. Journal on Financing for Development, 1(2), 68-107.

EU. (2008). Consolidated version of the treaty on European Union [2008] OJ C115/13.

European Commission. (2010). Communication from the Commission to the European Parliament, the Council and the European Economic and Social Committee, Tax and Development: Cooperating with Developing Countries on Promoting Good Governance in Tax Matters. COM (2010)163 final (21 April 2010).

European Commission. (2018). Press release-State aid: Commission finds Luxembourg gave illegal tax benefits to Engie; has to recover around $€ 120$ million. Retrieved August 30, 2019, from https://europa.eu/rapid/press-release_IP-18-4228_en.htm

European Commission. (2019). Data on taxation. Retrieved August 30, 2019, from https://ec. europa.eu/taxation_customs/business/economic-analysis-taxation/data-taxation_en

Evers, L., Miller, H., \& Spengel, C. (2013). Intellectual property box regimes: Effective tax rates and tax policy considerations. Retrieved October 7, 2019, from http://ftp.zew.de/pub/zew-docs/ dp/dp13070.pdf

FATF, \& Egmont Group of Financial Intelligence Units (EGMONT). (2013). Money laundering and terrorist financing through trade in diamonds. Retrieved June 26, 2020, from http://www. fatf-gafi.org/media/fatf/documents/reports/ML-TF-through-trade-in-diamonds.pdf

Financial Action Task Force (FATF). (2010). Money laundering vulnerabilities of free trade zones. Retrieved June 26, 2020, from http://www.fatf-gafi.org/media/fatf/documents/reports/ML\% 20vulnerabilities\%20of\%20Free\%20Trade\%20Zones.pdf

G8. (2013). Lough erne G8 leaders' communiqué. Retrieved June 15, 2017, from https://www.gov. uk/government/publications/2013-lough-erne-g8-leaders-communique

Gaessler, F., Hall, B. H., \& Harhoff, D. (2018). Should there be lower taxes on patent income? Retrieved May 21, 2019, from https://papers.ssrn.com/sol3/papers.cfm?abstract_id=3216471

Guenther, G. (2017). Patent boxes: A primer. Retrieved May 21, 2019, from https://fas.org/sgp/crs/ misc/R44829.pdf

Guvenen, F., Mataloni, R. J. Jr., Rassier, D. G., \& Ruhl, K. J. (2018). Offshore profit shifting and domestic productivity measurement. Retrieved October 17, 2019, from https://www. minneapolisfed.org/research/wp/wp751.pdf

Hearson, M. (2016). Measuring tax treaty negotiation outcomes: The Actionaid tax treaties dataset. Retrieved August 30, 2019, from https://core.ac.uk/download/pdf/46172854.pdf

Hebous, S., \& Klemm, A. (2018). A destination-based allowance for corporate equity. IMF Working Paper. Retrieved December 27, 2018, from https://www.imf.org/en/Publications/ WP/Issues/2018/11/08/A-Destination-Based-Allowance-for-Corporate-Equity-46314

Hwang, A. (2018). Thinking outside the (patent) box: An intellectual property approach to combating international tax avoidance. Retrieved October 17, 2019, from http:// rooseveltinstitute.org/wp-content/uploads/2018/05/Thinking-Outside-the-Patent-Box-final.pdf

IBFD. (2019). Tax research platform: Country surveys, country analyses, country key features. Retrieved May 9, 2019, from https://research.ibfd.org/

IMF. (2013). Issues in international taxation and the role of the IMF. Retrieved October 11, 2019, from http://www.imf.org/external/np/pp/eng/2013/062813.pdf

IMF. (2014). Spillovers in international corporate taxation. Retrieved June 26, 2014, from http:// www.imf.org/external/np/pp/eng/2014/050914.pdf

IMF. (2015). Current challenges in revenue mobilization-Improving tax compliance. Retrieved October 11, 2019, from https://www.imf.org/external/np/pp/eng/2015/020215a.pdf 
IMF. (2019a). IMF survey: IMF connects dots in spillover analysis of major economies. Retrieved October 11, 2019, from https://www.imf.org/en/News/Articles/2015/09/28/04/53/ socar090211b

IMF. (2019b). Spillover reports. Retrieved October 11, 2019, from https://www.imf.org/en/ Publications/SPROLLs/Spillover-Reports\#sort=\%40imfdate\%20descending

Keen, M., \& Mansour, M. (2009). Revenue mobilization in Sub-Saharan Africa: Challenges from globalization. Retrieved June 26, 2020, from https://www.imf.org/external/pubs/ft/wp/2009/ wp09157.pdf

Klemm, A., \& Van Parys, S. (2012). Empirical evidence on the effects of tax incentives. International Tax and Public Finance, 19, 393-423.

Kofler, G. (2012). Indirect credit versus exemption: Double taxation relief for intercompany distributions. Bulletin for International Taxation, 66(2), 77-89.

KPMG. (2018). Malta's tax system. Retrieved August 30, 2019, from https://home.kpmg/mt/en/ home/insights/2018/08/malta-tax-system.html

KPMG. (2019). Corporate tax rates table. Retrieved August 30, 2019, from https://home.kpmg/xx/ en/home/services/tax/tax-tools-and-resources/tax-rates-online/corporate-tax-rates-table.html

Lips, W., \& Cobham, A. (2018). Who will feature on the common EU blacklist of non-cooperative tax jurisdictions? Retrieved June 9, 2018, from https://www.researchgate.net/publication/ 326126153_Paradise_lost_Who_will_feature_on_the_common_EU_blacklist_of_non-coopera tive_tax_jurisdictions

Lusiani, N., \& Cosgrove, M. (2017). A strange alchemy: Embedding human rights in tax policy spillover assessments. Retrieved August 30, 2019, from https://papers.ssrn.com/ abstract $=3218597$

Lustig, N. (2018). Fiscal policy, income redistribution, an poverty reduction in low- and middleincome countries. In N. Lustig (Ed.), To equity handbook: Estimating the impact of fiscal policy on inequality and poverty. Washington, DC: Brookings Institution.

McGauran, K. (2013). Should the Netherlands sign tax treaties with developing countries? Retrieved May 28, 2019, from https://www.somo.nl/wp-content/uploads/2013/06/Should-theNetherlands-sign-tax-treaties-with-developing-countries.pdf

McNabb, K., \& LeMay-Boucher, P. (2014). Tax structures, economic growth and development. ICTD Working Paper 22. Retrieved June 26, 2020, from https://opendocs.ids.ac.uk/opendocs/ bitstream/handle/20.500.12413/10253/ICTD_WP22.pdf

Meinzer, M. (2016). Towards a common yardstick to identify tax havens and to facilitate reform. In P. Dietsch \& T. Rixen (Eds.), Global tax governance-What is wrong with it, and how to fix it. Colchester: ECPR Press.

Meinzer, M., \& Knobel, A. (2015). EU tax haven blacklist-A misguided approach? Retrieved April 19, 2016, from www.taxjustice.net/wp-content/uploads/2015/09/EU-tax-haven-blacklista-misguided-approach.pdf

Meinzer, M., Ndajiwo, M., Etter-Phoya, R., \& Diakité, M. (2019). Comparing tax incentives across jurisdictions: A pilot study. Retrieved June 26, 2020, from https://www.taxjustice.net/wpcontent/uploads/2018/12/Comparing-tax-incentives-across-jurisdictions_Tax-Justice-Net work_2019.pdf

Millán-Narotzky, L., Meinzer, M., \& Palanský, M. (2020). Who benefits from tax exemptions? Evidence of incentives for financial rents and environmental destruction. TJN Working Paper.

Mosquera Valderrama, I. J. (2019). The EU standard of good governance in tax matters for third (non-EU) countries. Intertax, 47, 454-467.

Neumayer, E. (2007). Do double taxation treaties increase foreign direct investment to developing countries? Journal of Development Studies, 43, 1501-1519.

OECD. (2011). Corporate loss utilisation through aggressive tax planning. Paris: OECD.

OECD. (2015). Countering Harmful Tax Practices More Effectively, Taking into Account Transparency and Substance, Action 5 - 2015 Final Report, OECD/G20 Base Erosion and Profit Shifting Project. Paris: OECD Publishing. 
OECD. (2019). OECD statistics: Table II.1. Statutory corporate income tax rate. Retrieved August 30, 2019, from https://stats.oecd.org/

Peeters, B., \& Hermie, T. (2011). Notional interest deduction: The Belgian experience. Retrieved March 31, 2019, from https://www.tiberghien.com/media/ACTL\%20seminarie_Bernard\& Thomas.pdf

Picciotto, S. (1992). International business taxation. A study in the internationalization of business regulation. Electronic Re-Publication ed. Retrieved April 26, 2019, from https://taxjustice.net/ cms/upload/pdf/Picciotto\%201992\%20International\%20Business\%20Taxation.pdf

Rao, K., Pitigala, S., Hoverter, M., \& Gauthier, JP. (2008). Special economic zones performance, lessons learned, and implications for zone development. Retrieved October 18, 2019, from http://documents.worldbank.org/curated/en/343901468330977533/pdf/ 458690WP0Box331s0April200801PUBLIC1.pdf

Romano, R., \& Campisano, M. (1981). Recouping losses: The case for full loss offsets. Northwestern University Law Review, 76, 709-744.

Sanz Gomez, R. (2015). The OECD's nexus approach to IP boxes: A European Union law perspective. WU International Taxation Research Paper Series No. 2015-12. Retrieved June 26, 2010, from https://ssrn.com/abstract $=2589065$

Tax Justice Network. (2019). Corporate tax haven index (CTHI) 2019 methodology. Retrieved June 4, 2019, from https://www.corporatetaxhavenindex.org/PDF/CTHI-Methodology.pdf

Yadav, S. (2017). Paradise papers: Yale University turned to offshore firm to enter India via Mauritius. The Indian Express. Retrieved June 25, 2020, from https://indianexpress.com/ article/india/paradise-papers-yale-university-india-investment-appleby-mauritius-black-moneymhrd-4928983/

Zeng, D. Z. (2010). How do special economic zones and industrial clusters drive. In D. Z. Zeng (Ed.), China's rapid development? Building engines for growth and competitiveness in China: Experience with special economic zones and industrial clusters. Washington, DC: World Bank.

Open Access This chapter is licensed under the terms of the Creative Commons Attribution 4.0 International License (http://creativecommons.org/licenses/by/4.0/), which permits use, sharing, adaptation, distribution and reproduction in any medium or format, as long as you give appropriate credit to the original author(s) and the source, provide a link to the Creative Commons license and indicate if changes were made.

The images or other third party material in this chapter are included in the chapter's Creative Commons license, unless indicated otherwise in a credit line to the material. If material is not included in the chapter's Creative Commons license and your intended use is not permitted by statutory regulation or exceeds the permitted use, you will need to obtain permission directly from the copyright holder.

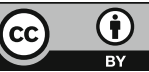

